ISSN 2236-0859

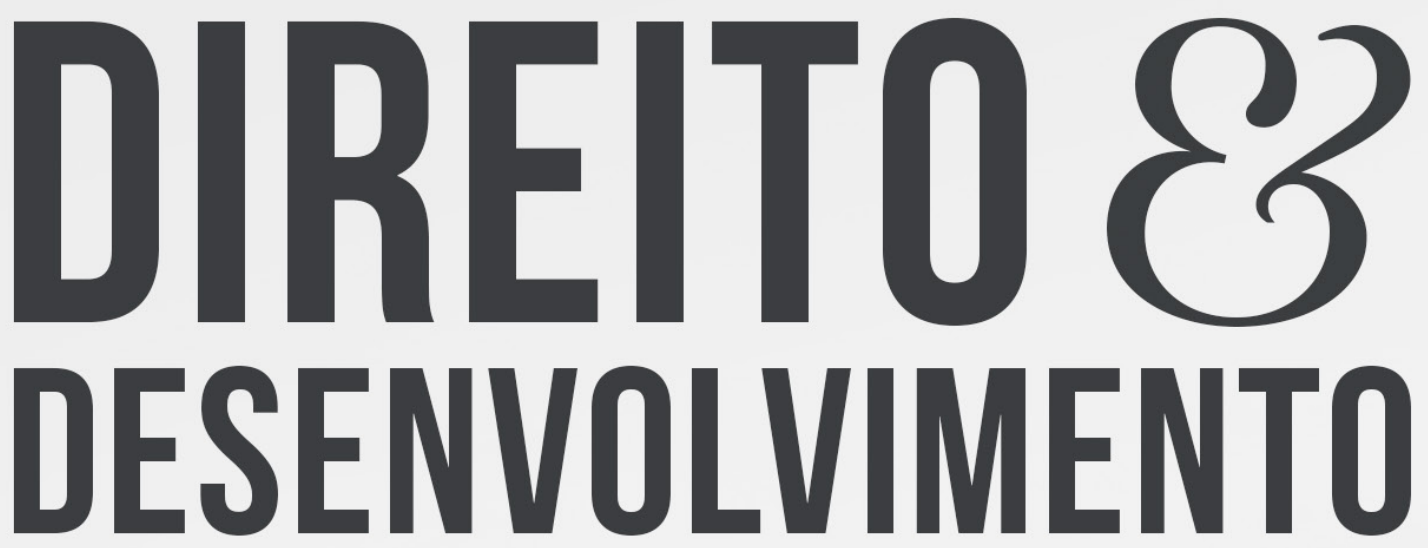

REVISTA DO PROGRAMA DE PÓS-GRADUAÇÃO EM DIREITO MESTRADO EM DIREITO E DESENVOLVIMENTO SUSTENTÁVEL

\title{
DO PARADIGMA DA COMPLEXIDADE À PRODUÇÃO NORMATIVA PROCESSUAL DEMOCRÁTICA
}

PAULO JUNIOR TRINDADE DOS SANTOS

GABRIELA SAMRSLA MOLLER

ANDRÉ ANTÔNIO GRACIOLI 


\title{
DO PARADIGMA DA COMPLEXIDADE À PRODUÇÃO NORMATIVA PROCESSUAL DEMOCRÁTICA
}

\section{FROM THE PARADIGM OF COMPLEXITY TO THE PRODUCTION OF DEMOCRATIC PROCEDURAL REGULATIONS}

Recebido: $14 / 12 / 2018$

Aprovado: 14/10/2019
Paulo Junior Trindade dos Santos ${ }^{1}$ Gabriela Samrsla Moller ${ }^{2}$ André Antônio Gracioli ${ }^{3}$

\section{RESUMO:}

Do paradigma da complexidade à produção normativa processual democrática inicia pelo estudo do paradigma da complexidade, no qual impera uma racionalidade reflexiva-aberta que pressupõe a transdisciplinariedade, ainda não assimilada pelo Direito, além do estudo da possibilidade de o Judiciário se tornar a porta de entrada para a assunção de tal paradigma pela ciência jurídica. O problema pode ser encontrado no paradigma da complexidade oriundo de um mundo global cada vez mais plural, no qual o Direito, ainda preso no paradigma mecanicista, não se abre à transdisciplinariedade. A hipótese é a possibilidade de internalização de tal paradigma pelo renovado papel do Judiciário, em que o processo é legitimado democraticamente e assume a função de formulação e concretização de direitos, sejam eles promessas constitucionais reprimidas ou novas demandas. Os objetivos são a preocupação em abordar o paradigma da complexidade e sua racionalidade aberta-reflexiva e, em seguida, apresentar o Judiciário e o Processo como elementos para adequar o Direito a tal paradigma. A metodologia utilizada é a bibliográfica. Com isso, busca-se analisar a relação entre a nova racionalidade e Processo, reflexão que se faz necessária ao Direito, dado que o antigo paradigma da ciência, fundado na unicidade e especialização de disciplinas e que culmina na Lei e no Código, vem a ser renovado pelo paradigma da complexidade.

Palavras-chave: Paradigma da Complexidade. Decisão Judicial. Processo. Democracia participativa.

\begin{abstract}
:
From the paradigm of complexity to normative procedural democratic production begins with the study of the paradigm of complexity, in which there is a reflexive-open rationality that presupposes transdisciplinarity, not yet assimilated by Law, besides the study of the possibility of the Judiciary becoming the gateway for the assumption of such a paradigm by legal science. The problem can be found in the paradigm of complexity arising from an increasingly plural world, in which law, still trapped in the mechanistic paradigm, does not open itself to transdisciplinarity. The hypothesis is the possibility of internalization of such a paradigm by the renewed role of 1 Doutor e Mestre em Direito pela UNISINOS. Professor junto ao Programa de Pós-Graduação em Direito da UNOESC-SC. Email: pjtrindades@hotmail.com

2 Mestrando em Direito pela UNISINOS-RS. Email: gabi.moller@hotmail.com

3 Mestranda em Direito pela UNOESC-SC. Email: andregraciolli@gmail.com
\end{abstract}


the Judiciary, in which the process is democratically legitimized and assumes the function of formulating and concretizing rights, be they repressed constitutional promises or new demands. The objectives are the concern in addressing the paradigm of complexity and its open-reflective rationality and then presenting the Judiciary and the Process as elements to adapt the Right to such a paradigm. The methodology used is the bibliographical one. The purpose of this study is to analyze the relation between the new rationality and Process, a reflection that is necessary for Law, since the old paradigm of science, based on the uniqueness and specialization of disciplines and culminating in Law and Code, comes to be renewed by the paradigm of complexity.

Keywords: Paradigm of Complexity. Judicial decision. Process. Participatory democracy.

\section{INTRODUÇÃO}

Do paradigma da complexidade à produção normativa processual democrática será balizado pelo estudo do paradigma da complexidade, em que se apresenta uma racionalidade reflexiva-aberta que pressupõe a transdisciplinariedade. Em um segundo momento, será realizado breve estudo acerca da possibilidade e legitimidade do Judiciário em internalizar tal paradigma ao Direito.

O problema pode ser encontrado no fato de que o paradigma da complexidade, presente em um mundo global cada vez mais plural, ainda não foi inteiramente absorvido pelo Direito, ainda preso ao paradigma mecanicista. A hipótese é a possibilidade de internalização de tal paradigma por um Judiciário de papel renovado, que busca a efetividade do Estado Democrático de Direito. Nesse sentido, o processo se torna instrumento político e se legitima a partir da ideia de democracia para além da representatividade, assumindo a possibilidade de concretizar mandamentos constitucionais e criar Direito a partir de novas demandas oriundas dessa sociedade complexa.

Os objetivos são abordar o paradigma da complexidade e sua racionalidade abertareflexiva e, em seguida, apresentar o Judiciário e o Processo como elementos possíveis de entrada de tal paradigma no Direito. A metodologia utilizada é a bibliográfica. Com isso, busca-se analisar a relação entre a nova racionalidade e Processo, reflexão que se faz necessária ao Direito, dado que o antigo paradigma da ciência, fundado na unicidade e especialização de disciplinas e que culmina na Lei e no Código, vem a ser renovado pelo paradigma da complexidade.

\section{PENSAR O DIREITO PELA NOVA ${ }^{4}$ RACIONALIDADE $^{5}$}

Na contemporaneidade, um novo mundo científico é instituído, tendo reflexos diretos no que se produz em sociedade e individualmente (produzimos a sociedade que nos produz ${ }^{6}$ ). A

\footnotetext{
4 Leia-se Nova como Novo, pois WARAT... fala do novo como o lugar em que cada um de nós pode descobrir-se a si mesmo. Em todo caso, o novo não como território de que se vislumbra a terra prometida, a exterioridade sonhada. É o novo como sensibilidade. (WARAT, Luis Alberto. A Ciência Jurídica e seus Dois Maridos. In: Territórios Desconhecidos. Volume I. A Procura Surrealista pelos Lugares do Abandono do Sentido e da Reconstrução da Subjetividade. Florianopolis: Fundação Boiteux, 2004, p. 86).

5 Importante salientar, para que em segundo momento se adentre nos aspectos relevantes da temática proposta, que LATAUR, evita as noções de crença, conhecimento, racionalidade e irracionalidade. Sempre que usadas, subvertem totalmente o quadro da ciência em ação, e o substituem por mentes, fenómenos e fatores deturpadores. Se quisermos continuar o estudo da rede da tecnociêncía, precisamos endireitar as crenças tortas e acabar com essa oposição entre ideias racionais e irracionais. (LATAUR, Bruno. Ciência em Ação. Como seguir Cientistas e Engenheiros Sociedade Afora. São Paulo: Editora Unesp, 200o, p. 302-303).

6 MORIN, Edgar. Da necessidade de um pensamento complexo. Para navegar no século XXI - Tecnologias do Imaginário e Cibercultura. Rio de Janeiro: Bertrand Brasil, 2005, p. 5.
} 
ciência, a partir de uma Nova Racionalidade ${ }^{7}$, tenta deixar para trás a razão fechada cartesiana, dado que a complexidade reflete a transdisciplinariedade, momento em que o conhecimento forma pontes entre as disciplinas com o intuito de abrir caminhos (novas possibilidades).

Parte-se da razão fechada (racionalismo que ocasiona a angústia cartesianamecanicista), em que o saber (reprodutivo ${ }^{8}$ ) é aprisionado e fechado hermeticamente em cada disciplina, para a abertura progressiva do edifício no qual se visualiza a imagem do progresso dos conhecimentos ${ }^{9}$. A ciência contemporânea, baseada na razão complexa (reconhece as zonas obscuras e as incertezas ${ }^{10}$ ), produz novos saberes e novas ignorâncias ${ }^{11}$ a partir das iniciativas, da cooperação, pelo sentido de responsabilidade, pela capacidade de relacionar umas coisas e fenômenos com outros e, assim, descobre a todo momento os agentes emergentes do novo ${ }^{12}$. Dessa maneira, ao dialogar com o irracional e o a-racional (ser e existência não são absurdos, nem racionais: eles são ${ }^{13}$ ), a razão complexa perpassa o conhecimento dualista cartesiano ${ }^{14} \mathrm{e}$ reflete o diálogo constante e prolixo imprescindível à convivência e complementação entre os saberes. Desse modo, a atualidade apresenta à cientificidade seu desafio: a complexidade ${ }^{15}$.

Dessa maneira, a Nova Racionalidade impõe irreversível transformação do conhecimento científico ${ }^{16}$, que se apresenta radical e progressivo, posicionando-se em coerência com as necessidades, os interesses e os desejos livremente expressados e contrastados com considerações éticas e estéticas ${ }^{17}$. Esboça e demarca o futuro da ciência, inserindo-se pela via da descentralização de disciplinas e desenvolvida por meio do descobrimento de níveis de realidade não traduzíveis diretamente a um projeto de ciência unitária, simplista e

7 VILAR, Sergio. La Nueva Racionalidad. Comprender la Complejidad con métodos transdisciplinarios. Barcelona: Editorial Kairós, 1997.

8 VILAR, Sergio. La Nueva Racionalidad. Comprender la Complejidad con métodos transdisciplinarios. Barcelona: Editorial Kairós, 1997, p. 13.

9 CERUTI, Mauro. El mito de la omnisciencia y el ojo del observador. In: WATZLAWICK, Paul; KRIEG, Peter. El ojo del observador. Contribuciones al constructivismo. Barcelona: Gedisa Editorial, 1995, p. 47.

10 MORIN, Edgar. Ciência com Consciência. Ed. revista e modificada pelo autor - 8" ed. - Rio de Janeiro: Bertrand Brasil, 2005, p. 168. 11 La ciencia contemporánea ha criticado la idea de enigma como ignorabius definitivo y fijado de una vez para siempre, produciendo nuevas áreas problemáticas y nuevas conceptualizaciones, nuevos saberes y nuevas ignorancias. La idea del enigma como limite absoluto estaba estrechamente vinculada con la adopción del ideal regulativo del lugar fundamental y neutro de observación. Es la plausibilidad heurística de este ideal la que desapareció en los últimos cien anos. (CERUTI, Mauro. El mito de la omnisciencia y el ojo del observador. In: WATZLAWICK, Paul; KRIEG, Peter. El ojo del observador. Contribuciones al constructivismo. Barcelona: Gedisa Editorial, 1995, p. 40, grifo nosso).

12 VILAR, Sergio. La Nueva Racionalidad. Comprender la Complejidad con métodos transdisciplinarios. Barcelona: Editorial Kairós, 1997, p. 13.

13 MORIN, Edgar. Ciência com Consciência. Ed. revista e modificada pelo autor - 8” ed. - Rio de Janeiro: Bertrand Brasil, 2005, p. 167-168.

$14 \mathrm{O}$ conhecimento do paradigma emergente tende assim a ser um conhecimento não dualista, um conhecimento que se funda na superação das distinções tão familiares e óbvias que até há pouco considerávamos insubstituíveis, tais como naturezacultura, natural-artificial, vivo-inanimado, mente-matéria, observador-observado, subjetivo-objetivo, coletivo-individual, animalpessoa. Este relativo colapso das distinções dicotômicas repercute-se nas disciplinas científicas que sobre elas se fundaram. Aliás, sempre houve ciência que se reconheceram mal nestas distinções e tanto que se tiveram de fracturar internamente para se lhes adequarem minimamente. Refiro-me à antropologia, à geografia e também à psicologia. Condensaram-se nelas privilegiadamente as contradições da separação de ciências naturais-ciências sociais. Daí, que, num período de transição entre paradigma, seja particularmente importante, do ponto de vista epistemológico, observar o que se passa nessas ciências (SANTOS, Boaventura de Souza. Um discurso sobre as Ciências. $7^{\underline{a}}$ ed.. Porto: Ediçoes Afrontamento, 1995, p. 39-40, grifo nosso).

15 Los desarrollos de las ciencias de nuestro siglo han hecho visibles muchos presupuestos de la herencia cartesiana, y han puesto en discusión la inevitabilidad y la necesidad de su identificación con las tareas y los criterios del conocimiento y de la ciencia. Así, la idea de previsión, la ciencia como ciencia de lo general, la conciencia del tiempo como lugar de despliegue de la necesidad atemporal de las leyes dejan de ser criterios absolutos y definitorios de la cientificidad. Se delinea un itinerario que a través de las fisuras de la presunta necesidad de los límites cartesianos de la ciencia produce lo que podemos definir como desafío de la complejidad (CERUTI, Mauro. El mito de la omnisciencia y el ojo del observador. In: WATZLAWICK, Paul; KRIEG, Peter. El ojo del observador. Contribuciones al constructivismo. Barcelona: Gedisa Editorial, 1995, p. 41).

16 KARL, Popper R.. Conjecturas y Refutaciones. Brasília: Editora da UnB, 1980, p. 264.

17 VILAR, Sergio. La Nueva Racionalidad. Comprender la Complejidad con métodos transdisciplinarios. Barcelona: Editorial Kairós, 1997, p. 227. 
disciplinária ${ }^{18}$. Com estes novos horizontes descentralizadores, passa a (re)avaliar o lugar do homem frente ao cosmos, inclusive o próprio modo de pensar o $\operatorname{cosmos}^{19}$.

Nesses termos, a Nova Racionalidade (apesar de parecer, em alguns momentos, surreal ${ }^{20}$ ) aguça a redescoberta da paixão pela vida, de compreender os outros, que virá de um confronto com os desejos que fluem marginalmente, perpassando a mera sobrevivência institucional(izada pelo direito) ${ }^{21}$. Contém e comporta, assim, novas proposições antropológicas e filosóficas que expressam novos modos de autoconhecimento, nos quais a razão não seja mutilada pela emoção, nem o sentir se expanda sem promovê-la. Com a conjunção de tais dimensões, provavelmente serão encontrados novos sentidos a nosso ser e a nosso deveni ${ }^{22}$.

Conforme Boaventura Sousa Santos, nenhuma forma de conhecimento é, em si mesma, racional; só a configuração de todas elas o é. Os conhecimentos tentam, pois, dialogar com seus pares, ocorrendo uma interpenetração ${ }^{23}$. Assim, essa nova maneira de pensar efetiva uma conversa transdisciplinar que reflexiona sobre uma nova forma de produção do conhecimento. Tal ocorre por meio do estabelecimento de vínculos entre coisas separadas e da recepção das diversas realidades geradas pelo complexo mundo, as quais aportam em certo grau de polissemia e processos singulares ${ }^{24}$. Nas palavras de Warat ${ }^{25}$, "Um saber sobre o Direito que reconcilie o homem com suas paixões, tenha respostas de acordo com o mundo $e$ transforme a estagnação de suas verdades em desejos vivos".

Dessa maneira, a ciência jurídica não passa ao largo de tal mudança paradigmática, exigindo uma nova compreensão (dialógo) dos saberes que se integram à sua dinâmica ${ }^{26}$, às complexidades do mundo, que interferem diretamente em seu funcionamento. Assim, sua funcionalidade não pode se apartar da compreensão plenária da vida que o jurista deve ajudar a resolver ${ }^{27}$.

A partir de tais contribuições, percebe-se que as complexidades do mundo global penetram no Direito por meio do Judiciário ${ }^{28}$, no qual o processo judicial adquire importância ${ }^{29}$

\footnotetext{
18 Se trata en primer lugar de las descentraciones espaciales, que provocaron la conquista del micro y macrocosmos. Pero son igualmente importantes las descentraciones temporales: así, es bastante difícil trazar una línea de demarcación precisa entre los dos procesos de descentración, espacial y temporal. En todas las imágenes de la realidad, el espacio y el tiempo estuvieron íntimamente conectados (CERUTI, Mauro. El mito de la omnisciencia y el ojo del observador. In: WATZLAWICK, Paul; KRIEG, Peter. El ojo del observador. Contribuciones al constructivismo. Barcelona: Gedisa Editorial, 1995, p. 50, grifo nosso).

19 CERUTI, Mauro. El mito de la omnisciencia y el ojo del observador. In: WATZLAWICK, Paul; KRIEG, Peter. El ojo del observador. Contribuciones al constructivismo. Barcelona: Gedisa Editorial, 1995, p. 49.

20 Em contraposição, os sonhos surrealistas mostram as razões que a razão instituída ignora; isto promove as lutas dos opostos, desarraigados e enraizados onde cada um assume a verdade de sua vida e seu fervor. É a fantasia no lugar dos fantasmas (WARAT, Luis Alberto. Territórios Desconhecidos. Volume I. A Procura Surrealista pelos Lugares do Abandono do Sentido e da Reconstrução da Subjetividade. Florianopolis: Fundação Boiteux, 2004, p. 188).

21 WARAT, Luis Alberto. A Ciência Jurídica e seus Dois Maridos. In: Territórios Desconhecidos. Volume I. A Procura Surrealista pelos Lugares do Abandono do Sentido e da Reconstrução da Subjetividade. Florianopolis: Fundação Boiteux, 2004, p. 76.

22 VILAR, Sergio. La Nueva Racionalidad. Comprender la Complejidad con métodos transdisciplinarios. Barcelona: Editorial Kairós, 1997, p. 174.

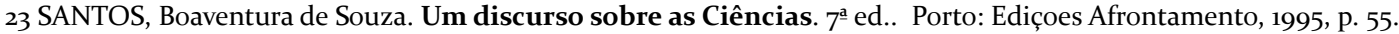
24 WARAT, Luis Alberto. Metáforas para a Ciência, a Arte e a Subjetividade. In: Territórios Desconhecidos. Volume I. A Procura Surrealista pelos Lugares do Abandono do Sentido e da Reconstrução da Subjetividade. Florianopolis: Fundação Boiteux, 2004, p. 531.

25 WARAT, Luis Alberto. A Ciência Jurídica e seus Dois Maridos. In: Territórios Desconhecidos. Volume I. A Procura

Surrealista pelos Lugares do Abandono do Sentido e da Reconstrução da Subjetividade. Florianopolis: Fundação Boiteux, 2004, p. 83-84.

26 CALDANI, Miguel Ángel Ciuro. Estrategia Jurídica. Rosario: Consejo de Investigaciones Universidad Nacional de Rosario, 2011, p. 106 e 98.

27 CALDANI, Miguel Ángel Ciuro. Estrategia Jurídica. Rosario: Consejo de Investigaciones Universidad Nacional de Rosario, 2011, p. 98.

28 Neste ponto ver: que aponta a postura inovadora do STF reconhecendo que o direito deve buscar informações fora do âmbito de sua ciência assim dialogando com as demais ciências. (ALHO, Ana Maria Gomes da Silva. Transdisciplinariedade no STF - A ADI n. ${ }^{\circ}$ 3510. Anais do XIX Encontro Nacional do CONPEDI.)

29 A tendência apontada pela sociedade atual e de que projete: "o processo a ser a rainha das ciências jurídicas". (COUTURE, J.

Eduardo. Introdução ao Estudo do Processo Civil. $3^{a}$ Ed. Rio de Janeiro: José Konfino Editor, 1970, p. 8o.)
} 
tanto para a Teoria do Direito quanto para a vida ${ }^{30}$, podendo ser visto como capaz de absorver o paradigma da complexidade e fazer, assim, as pontes entre as ciências, refletidas na Decisão Jurídica de epistemologia construtivista ${ }^{31}$.

Um dos caminhos apontados para a projeção do Direito pela Nova Racionalidade seria o Direito Reflexivo ${ }^{32}$ e o Direito Responsivo ${ }^{33}$, que aportam o paradigma da complexidade e apresentam translucidez científica contemporânea para responder à sociedade e aos seus indivíduos, seus desejos e necessidades, tendo como moradia sólida a transdisciplinariedade.

\section{EM DIREÇÃO AO PARADIGMA DA COMPLEXIDADE}

O paradigma é considerado o que está no princípio da construção das teorias, o núcleo obscuro que orienta os discursos teóricos neste ou naquele sentido ${ }^{34}$, a unidade fundamental para o estudo do desenvolvimento científico, a qual não pode ser totalmente reduzida a componentes atômicos lógicos ${ }^{35}$. O paradigma da complexidade contém estrutura mítica que se apresenta via razão complexa, a qual engloba razões instrumentais que se desenvolvem em seu interior: é visto como 'o fogo das loucuras que desemboca no teatro-mundo' ou, ainda, como 'labirinto', ambos de razões míticas ${ }^{36}$. Assim, a racionalidade em seu seio é mais plural, tornando o conhecimento novamente aventura encantada ${ }^{37}$ e surreal ${ }^{8}$, abrindo caminhos para compreender melhor os problemas humanos ${ }^{39}$.

30 Una sencilla observación empírica demuestra que en todas las sociedades suelen haber ciertas personas ante las cuales se plantean problemas jurídicos, problemas relacionados con la efectividad de las reglas de Derecho que rigen la vida familiar, civil, comercial, laboral, etc., de la correspondiente comunidad, y que esas selectas personas tienen la particularidad de que frente al problema suelen formular una conclusión (veredicto, fallo, laudo, sentencia), que es la "última palabra" al respecto y que debe ser acatada -y normalmente lo es- por todos (incluso el Estado). y bien, la actividad que se desarrolla en orden a este veredicto, fallo, laudo o sentencia, se identifica -en términos muy genéricos-con la expresión "proceso jurisdiccional. La importancia que este proceso jurisdiccional adquiere no solamente en la Teoría del Derecho sino en la misma vida social, se advierte fácilmente en cuanto se tiene presente que tan sólo en nuestro país existen al redor de quinientos órganos del Estado ante los cuales se desarrollan tales procesos (además de innúmeros tribunales arbitrales), y que ante cada uno de dichos órganos (cuando se trata de órganos del Estado) se llevan a cabo-simultáneamente- varios cientos (y a veces miles) de procesos. Es que de esos procesos jurisdiccionales depende en última instancia la vigencia de todo el ordenamiento jurídico que la comunidad en cuestión se ha dado, y es a ellos que acuden todas las personas que entienden que se encuentran afectadas por la falta de correlación entre lo que las normas jurídicas dicen que debe ser y lo que ocurre en la realidad de la vida. (OLIU, Alejandro Abal. Derecho Procesal. Tomo I. Segunda Edición, Revisada Y Actualizada. Uruguay: Fundación De Cultura Universitaria, 2001, p. 11, grifo nosso).

31 Derecho y Complejidad. In: CARCOVA, Carlos Mária. Las Teorias PostPositivistas. 3 ed. Buenos Aires: AbeledoPerrot, 2009, p. 263.

32 TEUBNER e BOURDIEU aludem que o Direito Reflexivo surge como resposta aos problemas das sociedades contemporâneas que se caracterizam pelo alto nível de complexidade, tendo como papel estruturar e reestruturar os sistemas sociais semiautônomos, modelando tanto seus procedimentos de discurso interno como seus métodos de coordenação com outros sistemas sociais. BOURDIEU, Pierre; TEUBNER, Gunther. La fuerza del derecho. Bogotá: Siglo del Hombre Editores. Facultad de Derecho de la Universidad de los Andes, Ediciones Uniandes, Instituto Pensar, 2000.

33 NONET y SELZNICK corroboram que o direito responsivo resulta da crise do formalismo legal, e assim evoluciona o direito, emergindo da combinação entre finalismo e participação, que passa a nortear as necessidades e aspirações sociais, voltando-se à efetividade substantiva de suas disposições e à capacidade de solução de problemas sociais. NONET, Philippe; SELZNICK, Philip. O Direito e Sociedade: a transição ao sistema jurídico responsivo. Rio de Janeiro: Editora Revan, 2010.

34 MORIN, Edgar. Ciência com Consciência. Ed. revista e modificada pelo autor - 8” ed. - Rio de Janeiro: Bertrand Brasil, 2005, p. 45.

35 KUHN, Thomas S. A Estrutura das Revoluções Científicas. $7^{\mathfrak{a}}$ ed. São Paulo: Perspectiva, 2003, p. 31.

36 HINKELAMMERT, Franz. La maldición que pesa sobre la ley. Las raíces del pensamiento crítico en Pablo de Tarso. San José: Costa Rica: Editorial Arlekin, 2010, p. 69.

37 SANTOS, Boaventura de Souza. Um discurso sobre as Ciências. $7^{a}$ ed.. Porto: Edições Afrontamento, 1995, p. 35.

38 Como acima mencionado e aludido em nota de rodapé quanto ao tema e alento. (WARAT, Luis Alberto. A Ciência Jurídica e seus Dois Maridos. In: Territórios Desconhecidos. Volume I. A Procura Surrealista pelos Lugares do Abandono do Sentido e da Reconstrução da Subjetividade. Florianopolis: Fundação Boiteux, 2004, p. 91 e segs).

39 ORIN, Edgar. Da necessidade de um pensamento complexo. Para navegar no século XXI - Tecnologias do Imaginário e Cibercultura. Rio de Janeiro: Bertrand Brasil, 2005, p. 5. 
O paradigma da simplificação e dos saberes fracionados (redução/separação), retrato de uma família intelectual numerosa e instável ${ }^{40}$ cujo auge ocorreu nos anos $70^{41}$, teve colocado em dúvida seu objetivismo e seu rigorismo científico a partir da percepção da desordem que se estabelecia em sua racionalidade. Com isso, os físicos Bohr e Heisenberg apresentaram inovações epistemológicas e experimentais que possuíam visão de mundo similar à mística de outras épocas ${ }^{42}$, tendo as demais ciências assimilado tais feitos e questionado o absolutismo da objetividade científica ${ }^{43}$.

Tal marco histórico agregado a outros acontecimentos científicos propiciou ao pensamento complexo inserir o homem no processo de conhecimento ${ }^{44}$, impulsionando outros modos de construção mental e do real, outras formas mais flexíveis de organizar nossas representações mentais e o diálogo com formas transdisciplinares de racionalizar. O paradigma da complexidade acontece, assim, a partir do diálogo, da vontade de cooperar, do rechaço ao dogmatismo autoritário e a outras formas de dominação ${ }^{45}$.

Na contemporaneidade, presta-se atenção à dimensão plenária e universal ao falar de mundos e não de mundo, no qual cada um desses mundos está em plena comunicação com os demais, possuindo ao menos uma imagem dos outros ${ }^{46}$. Os entrecruzamentos, imbricamentos e rupturas destes mundos constituem o paradigma da complexidade que, ao mesmo tempo, separa e associa, concebendo níveis de emergência da realidade sem reduzi-los às unidades elementares e às leis gerais ${ }^{47}$.

Este novo paradigma encontra rumos para apresentar uma inovação metodológica ${ }^{48}$ que se fortalece na confluência crescente entre disciplinas (sem prescindir de suas especialidades). A interpretação ao aprender-compreender-explicar-gestionar cada fato complexo ocorrerá tal como realmente é e está: composto por fatores históricos-naturais-técnicos, os quais se heterogenizam sem interrupção, em uma medida e outra ${ }^{49}$. Supõe-se ainda que sua natureza se estruture em processo auto-organizativo com diferentes níveis, fazendo com que necessariamente se dê uma explicação unificada dos fenômenos, impondo revisão da razão

\footnotetext{
40 SANTOS, Boaventura de Souza. Um discurso sobre as Ciências. $7^{\text {a }}$ ed.. Porto: Edições Afrontamento, 1995 , p. 35. 41 El viejo paradigma legitimo el establecimiento de los saberes fraccionados apoyándose, además, en la utilidad que brindaban a la industrialización en sus primeras etapas - necesidad de especialistas-, así como en su expansión hasta los años 1970, aproximadamente. (VILAR, Sergio. La Nueva Racionalidad. Comprender la Complejidad con métodos transdisciplinarios. Barcelona: Editorial Kairós, 1997, p. 16.)

42 CAPRA, Fritjof. El Tao de la Física. Una exploración de los paralelismos entre la física moderna y el misticismo oriental. 9aㅡ ed.. Malagra: Sirio, 200o, p. 20.

43 VILAR, Sergio. La Nueva Racionalidad. Comprender la Complejidad con métodos transdisciplinarios. Barcelona: Editorial Kairós, 1997, p. 54.

44 WARAT, Luis Alberto. Territórios Desconhecidos. Volume I. A Procura Surrealista pelos Lugares do Abandono do Sentido e da Reconstrução da Subjetividade. Florianopolis: Fundação Boiteux, 2004, p. 173.

45 Pódese conferir que el paradigma de la complejidad y sus nuevas formas de razonar transdisciplinariamente, requiere asumir muchos otros conceptos y actitudes: requiere, nada menos (ya lo he sugerido), la reforma de nuestras mentalidades, otros modos de construcción mental de lo real, otras formas, más flexibles, de organizar nuestras representaciones mentales, dejándolas abiertas a su posible transformación. En este sentido, cuantos trabajamos en los ámbitos de la transdisciplinariedad, recomendamos (y nos exigimos) la práctica del principio de humildad de tipo socrático. Los científicos transdisciplinarios explicitan constantemente ese principio de maneras archilocuentes (VILAR, Sergio. La Nueva Racionalidad. Comprender la Complejidad con métodos transdisciplinarios. Barcelona: Editorial Kairós, 1997, p. 37-38).

46AUGE, Marc. Hacia una Antropología de los Mundos Contemporáneos. Barcelona: Gedisa, 1998. P. 123.

47 MORIN, Edgar. Ciência com Consciência. Ed. revista e modificada pelo autor - 8” ed. - Rio de Janeiro: Bertrand Brasil, 2005, p. 138.

48 Transdisciplinarità e Dialogo. Nuova Umanità. XXIX (2007/3) 171, pp. 353-36o, p. 354-355.

49 VILAR, Sergio. La Nueva Racionalidad. Comprender la Complejidad con métodos transdisciplinarios. Barcelona: Editorial Kairós, 1997, p. 16.
} 
lógica científica, focando a atenção no método transdisciplinar ${ }^{5^{\circ}}$, capaz de integrar os diversos contributos ${ }^{51}$.

Nesse paradigma, portanto, os fenômenos complexos articulam-se com a transdisciplinaridade ${ }^{52}$, com as realidades e os problemas, realizando-se diálogo imprescindível para convivência e complementação entre os saberes ${ }^{53}$. Nesse sentido, a contemporaneidade tende para o conhecimento multidimensional ${ }^{54}$ (o conhecimento deve corresponder ao conjunto de complexidades ${ }^{55}$ ), o qual permite dividir relativamente esses domínios científicos sem prescindir da comunicação que não opera a redução ${ }^{5}$. Revela, portanto, a tentativa de superar a angústia ${ }^{57}$ de se renovar frente à tecnociência e à globalização, que alteraram as noções de tempo e espaço, projetando necessidade de novas e melhores estratégias de produção do conhecimento ${ }^{8}$.

Assim, a transdisciplinariedade transforma nosso olhar sobre o individual, o cultural e o social, remetendo para a reflexão respeitosa e aberta sobre as culturas do presente e do passado, do Ocidente e do Oriente ${ }^{59}$. O Direito é inserido em tal paradigma, impactando e sendo impactado por outras disciplinas científicas $^{60}$, sendo a comunicação com as outras

50 La transdisciplinariedad es una concepción mucho más reciente. La propia complejidad del mundo en que vivimos nos obliga a valorar los fenómenos interconectados. Las actuales situaciones físicas, biológicas, sociales y psicológicas no actúan sino interactúan recíprocamente. La descripción del mundo y de los fenómenos actuales nos exige una nueva forma de valoración desde una perspectiva más amplia, con una nueva forma de pensar que reclama encontrar un nuevo paradigma capaz de interpretar la realidad actual. A esto nos lleva la concepción transdisciplinaria. (MATOSI, Nuria Esther Pérez; QUESADAII, Emilio Setién. La interdisciplinariedad y la transdisciplinariedad en las ciencias: una mirada a la teoría bibliológico-informativa. Acimed. 2008;18(4). Disponible en: Dirección electrónica de la contribución.

51 Tutto ciò richiede di riesaminare le relazioni che intercorrono tra le varie forme del sapere, e quindi il collegamento tra le discipline interessate a tale processo. A riguardo la tendenza odierna è quella di abbandonare il metodo interdisciplinare, considerato sempre più un rimedio ai tentativi riduzionisti e al disfacimento dello scientismo, focalizzando l'attenzione sul metodo transdisciplinare ritenuto capace di poter sostenere e integrare i diversi contributi con cui è scrutata la realtà. (Transdisciplinarità e Dialogo. Nuova Umanità. XXIX (2007/3) 171, p. 353-36o e p.354-355).

52 O que vem a significar o ora termo: etimologicamente, trans é o que está ao mesmo tempo entre as disciplinas, através das diferentes disciplinas e além de todas as disciplinas, remetendo também à idéia de transcendência. O senso comum intui que todas essas inter-relações ocorrem no mundo e na vida. No entanto, uma vez que sempre seremos principiantes na compreensão, na incorporação e na implementação dessas inter-relações, devido à sua imensa complexidade, como levá-las à educação e à pesquisa? É para responder a essa pergunta que, após revisitar, com respeito, rigor e inclusão as epistemologias, os métodos, as noções de valor, de sentido, o conceito de ciência, de pesquisa, de competência, os contextos, as estruturas e dados e percepções a respeito das dimensões internas do ser humano, a Transdisciplinaridade traz sua própria contribuição integradora. (MELLO, Maria F. de; BARROS, Vitória Mendonça de; SOMMERMAN, Américo. Introdução. In: Educação e Transdisciplinaridade II. Coordenação executiva do CETRANS. - São Paulo : TRIOM, 2002, p. 10, grifo nosso).

53 FAGÚNDEZ, Paulo Roney Ávila. Os novos direitos à luz da transdisciplinaridade: o resgate de um humanismo radical e a promoção da ecologia na sociedade do mal-estar. In: Espaço Jurídico, Joaçaba, v. 9, n. 1, p. 57-66, jan./jun. 20o8, p. 6o-61.

54 El hombre no es exclusivamente un conjunto de necesidades, sino también de deseos, que van más allá de las necesidades, y que conciernen a nuestras articulaciones con la belleza y con los sistemas de valores. El ser humano es multidimensional y resulta incomprensible si o se observa todas sus dimensiones integradas-intrincadas. (VILAR, Sergio. La Nueva Racionalidad. Comprender la Complejidad con métodos transdisciplinarios. Barcelona: Editorial Kairós, 1997, p. 139).

55 Es necesario crear un modo de conocimiento que corresponda a ese conjunto de complejidades, que se transforman a lo largo tiempo histórico (general), y a través de la infinidad de temporalidades características individuales, dentro de la corriente de la irreversibilidad. El conjunto de todo ello se auto-organiza y evoluciona, según sean en cada momento las construcciones mentales que se hagan los individuos, y también según las representaciones del pasado que perduren en su conciencias. (VILAR, Sergio. La Nueva Racionalidad. Comprender la Complejidad con métodos transdisciplinarios. Barcelona: Editorial Kairós, 1997, p. 140.)

56 MORIN, Edgar. Ciência com Consciência. Ed. revista e modificada pelo autor - 8” ed. - Rio de Janeiro: Bertrand Brasil, 20o5, p. 177 e 138 .

57 BAUMAN, Zygmund. Tempo e Classe; Lei Global, Ordens Locais. In: Globalização: As consequências humanas. Rio de Janeiro: Jorge Zahar Editor, 1999; In: Vidas desperdiciadas. La modernidade y sus parias. Buenos Aires: Paidos, 2003.; Emancipação; Individualidade; Tempo-Espaço. In: Modernidade Líquida. Rio de Janeiro: Zahar, 20o1; Las Consecuencias Perversas de la Modernidad. Modernidade, Contingencia y Riego. Barcelona: Anthropos, 1996.

58 CARRIZO, Luis; PRIETO, Mayra Espina; KLEIN, Julie T.. Transdisciplinariedad y Complejidad en el Análisis Social. Gestión de las Transformaciones Sociales (MOST) Documento de Debate. UNESCO. Organizacion de las Naciones Unidas para la Educacion, la Ciencia y la Cultura, p. 7 .

59 MELLO Maria F.de;BARROS, Vitória Mendonçade;SOMMERMAN,Américo. Introdução. In:EducaçãoeTransdisciplinaridade II. Coordenação executiva do CETRANS. - São Paulo : TRIOM, 2002, p. 8-9.

6o Es así entonces como el Derecho es impactado e impacta a su vez a otras disciplinas que tienen como objetoal ser humano, bastará un simple vistazo a la forma como se estructuran las normas e instituciones legales para apreciar así que la Psicología, la Sociología, la Filosofía, la Economía, la Políticas y hasta la Religión hacen vida disciplinaria y se relación constantemente con la formación del Derecho. (ARAUJO, Eglis; SOSA, José Gregorio. El Objeto del Derecho desde el contexto de la Multidisciplinariedad, Interdisciplinariedad y Transdisciplinariedad. Una Vision de los Autores. Barquisimeto, Agosto de 2012, p. 3, grifo nosso). 
ciências possibilitadora de novas articulações e novos conhecimentos transdisciplinários com finalidade coexistencial ${ }^{61}$. Assim, na medida em que as sociedades complexas passam a ser o motor de transformações de novas realidades, que aportarão por meio do processo judicial no Direito, deste se passa a exigir a conversação com as demais áreas científicas.

Assim é que a complexidade faz com que na contemporaneidade sejam superadas as simplistas aproximações interdisciplinárias ${ }^{62}$ (onde cada disciplina pretende primeiro fazer reconhecer sua soberania territorial ${ }^{63}$ ) e a mera especialidade e a unicidade das disciplinas, as quais parecem estar muito longe de servir como referência para construção satisfatória da Ciência Jurídica ${ }^{64}$. Portanto, a transdisciplinariedade é a resposta para o paradigma da complexidade, dado que o "conocimiento no sólo se desarrolla verticalmente, hacia lo hondo, sino también horizontalmente, en conexión con otras materias-disciplinas"65.

Na medida em que "existen fenómenos sociales cuyo estudio sobrepasan los limites de las disciplinas; de tal manera que sus aproximaciones solo pueden ser entendidas através de los contextos transdiciplinarios, los cuales generan nuevos datos que entre si las distintas normas de Derecho"66, observa-se a estreita vinculação entre a complexidade e o Direito. Nessa medida, a decisão jurídica aparece, conforme já mencionado, como centro de gravidade. A ciência jurídica necessita enfrentar a crise dos antigos paradigmas dominantes (legalista, estadista e positivista), os quais afetam em larga escala todos os ramos do direito ${ }^{67}$, dada a necessidade de adaptação à nova proposta de racionalidade oriunda da complexidade global.

\section{COMPLEXIDADE E PRODUÇÃO NORMATIVA PROCESSUAL DEMOCRÁTICA $^{68}$}

Diante desse quadro de pluralidade e complexidade social que reclama novas e adequadas soluções pelo Direito, cabe a análise de como a função jurisdicional se coaduna com o paradigma da complexidade. Assim, em virtude das ausências (deliberadas ou não) dos Poderes Executivo e Legislativo no cumprimento dos mandamentos constitucionais ${ }^{69}$ e na regulação das pretensões sociais, o Judiciário (por meio do processo) surge como alternativa para aperfeiçoar o Direito como adequação social.

61 Transdisciplinarità e Dialogo. Nuova Umanità. XXIX (2007/3) 171, pp. 353-36o, p. 356.

62 La complejidad de lo real, el estudio y la gestión de casi todos los problemas, exigen aproximaciones interdisciplinarias. Contra la fragmentación autárquica de las disciplinas, una nueva concepción de la objetividad científica se expande al iluminar el carácter complementario y no contradictorio de las ciencias experimentales, que crean y manipulan sus objetos, y las ciencias narrativas, que tienen como problema las historias que se construyen creando su propio sentido. (VILAR, Sergio. La Nueva Racionalidad. Comprender la Complejidad con métodos transdisciplinarios. Barcelona: Editorial Kairós, 1997, p. 62, grifo nosso).

63 Sabemos cada vez mais que as disciplinas se fecham e não se comunicam umas com as outras. Os fenômenos são cada vez mais fragmentados, e não se consegue conceber a sua unidade. É por isso que se diz cada vez mais: "Façamos interdisciplinaridade." Mas a interdisciplinaridade controla tanto as disciplinas como a ONU controla as nações. Cada disciplina pretende primeiro fazer reconhecer sua soberania territorial, e, à custa de algumas magras trocas, as fronteiras confirmam-se em vez de se desmoronar. (MORIN, Edgar. Ciência com Consciência. Ed. revista e modificada pelo autor - 8” ed. - Rio de Janeiro: Bertrand Brasil, 2005, p. 135-136, grifo nosso).

64 CALDANI, Miguel Ángel Ciuro. El Derecho Universal (Perspectiva para la Ciencia Jurídica de una Nueva Era). Rosario: Fundaciones para las Investigaciones Jurídicas, 2001, p. 25.

65 VILAR, Sergio. La Nueva Racionalidad. Comprender la Complejidad con métodos transdisciplinarios. Barcelona: Editorial Kairós, 1997, p. 44 .

66 ARAUJO, Eglis; SOSA, José Gregorio. El Objeto del Derecho desde el contexto de la Multidisciplinariedad, Interdisciplinariedad y Transdisciplinariedad. Una Vision de los Autores. Barquisimeto, Agosto de 2012 , p. 4.

67 OST, François. La thèse de doctorat en droit: du projet à la soutenance. Disponível em: <http://www.usaintlouis.be/fr/pdf/ Droit/rapport_fr.pdf>. Acessado em: 21-08-2013. p. 13.

68 Repensar o processo e a jurisdição em sua função e estrutura, ver: SANTOS, Paulo Trindade. Filosofia do Direito Processual (da jurisdição ao processo): fenômeno conflitológico de interesses como gênese do Direito. Tese Doutorado. Unisinos, PPGD, São Leopoldo, RS, 2018.

69 Ou seja, em nosso País as promessas da modernidade ainda não se realizaram. Só que existe um imenso déficit social em nosso País, e por isso temos de defender as instituições da modernidade contra as tentativas de enfraquecimento do Estado. [...] (daí) a importância da função judicial enquanto possível interpretação e aplicação progressiva e criadora do ordenamento jurídico na sua totalidade, colocandose, nesse contexto, necessariamente a Constituição como instância máxima para aferição do sentido das normas (STRECK, Lenio Luiz. Jurisdição Constitucional e Decisão Jurídica. 4. ed. São Paulo: Editora Revista dos Tribunais, 2014, p. 89 e 104). 
Assumir quea função jurisdicional é constitucionalmente competente para tal desiderato pressupõe um diferente entendimento acerca da sua legitimidade democrática, transpondo a barreira da democracia representativa (em virtude de suas promessas não cumpridas ${ }^{70}$ ) rumo a novos horizontes. Requer, também, a retirada do véu que liga a vontade geral à vontade legislativa ${ }^{71}$, especialmente no que concerne aos países de modernidade tardia, como o Brasil, em que a lei garante a abstração, mas sua ausência de efetividade ${ }^{72}$ pelos poderes competentes acaba por esvaziar o sentido de plus normativo ${ }^{73}$ do Estado Democrático de Direito.

Nesse sentido é que o processo assume outras feições além de meio adequado, estabelecido pelo Estado e à disposição das partes, para resolução dos conflitos de interesse individuais ${ }^{74}$. O processo, no âmbito do Estado Democrático de Direito, assume a importante função de ser instrumento de participação política75, na tentativa de perpassar a democracia representativa $^{76}$, culminando, ao cabo, na consagração da expressão ativismo judicial ${ }^{77}$.

70 [...] a) a primeira promessa descumprida é a de que os regimes democráticos seriam monoliticamente unitários, cujo centro exclusivo de poder estaria concentrado no Estado, sem a existência de quaisquer "corpos intermediários" que pudessem interpor-se entre aquele e os cidadãos individualmente considerados. [...] b) a segunda promessa não cumprida foi a de que o mandato popular conferido aos representantes políticos da nação não seria vinculado, mas essencialmente político, quer dizer livre, no sentido de que o eleito, a partir de sua investidura, deixaria de representar o eleitor para transformar-se no legítimo representante dos "interesses gerais” da nação. [...] c) A terceira promessa igualmente esquecida pela prática democrática diz respeito à indesejável persistência das oligarquias nas democracias contemporâneas. Quer dizer, a promessa fundamental em que se baseava o modelo rousseauniano o para o qual a preservação da liberdade política dos cidadãos decorria de sua sujeição apenas às leis por eles próprios aprovadas e consentidas - perdeu-se ao contato com a realidade histórica (SILVA, Ovídio Baptista da. Democracia Moderna e Processo Civil. In: GRINOVER, Ada Pellegrini; DINAMARCO, Cândido Rangel; WATANABE, Kazuo. Participação e Processo. São Paulo: Editora Revista dos Tribunais, 1988, p. 105-107).

71 El derecho se reduce así a ley: um sistema de reglas autoritarias, de mandatos pensados y queridos abstractos e inelásticos, incriticable en su contenido, ya que su autoridad procede no de sua propria cualidad sino de la cualidad del sujeto legislador. Pronto, en el clima prerrevolucionario y revolucionario, la ley tendrá un refuerzo posterior, el democrático, gracias a la afirmada (aunque no demostrada) coincidência entre voluntad legislativa y voluntad general. [...] La verdade incuestionable de que la ley y sólo la ley expresa la voluntad general y, como tal, produce y condiciona toda manifestación de juridicidad aparece así, para el historiador del derecho, cargada de vetas ideológicas; es decir, todo cuanto viene propuesto como verdad se presenta, en um examen más minucioso, más bien como uma pseudoverdad tuteladora en última instancia de los intereses particulares de los titulares del poder (GROSSI, Paolo. Mitología Jurídica de la modernidad. Madrid: Editorial Trotta, 2003, p. 34-42).

72 [...] é fundamental destacar a importância da efetividade dentro dos pressupostos constitucionais do Estado Democrático de Direito. De acordo com nosso entendimento, ela, a efetividade, compõe um dos elementos integrantes desta concepção de Estado, na medida em que contribui para a construção de uma sociedade mais justa (art. $3^{-o}$, inc. I, da CF), baseada na dignidade da pessoa humana (art. $\mathbf{1}^{\mathbf{0}}$, inc. III, da CF), pois de acordo com Rui Barbosa, a justiça prestada de forma tardia equivale à injustiça qualificada. Neste diapasão, podemos seguramente afirmar que existe o dever constitucional de promover a efetividade do direito quer em nível da função judicial, administrativa ou mesmo legislativa, em todas as esferas do poder: federal, estadual e municipal (RIBEIRO, Darci Guimarães. Da tutela jurisdicional às formas de tutela. Porto Alegre: Livraria do Advogado Editora, 2010, p. 8o).

73 STRECK, Lenio Luiz. Jurisdição Constitucional e Decisão Jurídica. 4. ed. São Paulo: Editora Revista dos Tribunais, 2014 , p. 101. $74 \mathrm{O}$ monopólio não cria para o Estado o dever de prestar qualquer tutela jurisdicional, senão a tutela jurisdicional apropriada ao direito material que a parte traz a juízo, é dizer, o Estado titular da potestade jurisdicional deve colocar à disposição dos cidadãos um instrumento (processo) capaz de amoldar-se aos interesses em conflito, para poder assim proporcionar justiça em um tempo adequado aos consumidores dos serviços jurisdicionais, na feliz ótica de CAPPELLETTI, Acesso ala giustizia come programma di reforma e come método di pensiero. In: Revista di Diritto Processuale, 1982, p. 243 e ss. (RIBEIRO, Darci Guimarães, Da Tutela Jurisdicional às Formas de Tutela. Porto Alegre: Livraria do Advogado Editora, Livraria do Advogado, 2010, p. 37).

75 Acredito estejamos caminhando para o processo como instrumento político de participação. A democratização do Estado alçou o processo à condição de garantia constitucional; a democratização da sociedade fá-lo-á instrumento de atuação política. Não se cuida de retirar do processo sua feição de garantia constitucional, sim fazê-lo ultrapassar os limites da tutela dos direitos individuais, como hoje conceituados. Cumpre proteger-se o indivíduo e as coletividades não só do agir contra legem do Estado e dos particulares, mas de atribuir a ambos o poder de provocar o agir do Estado e dos particulares no sentido de se efetivarem os objetivos politicamente definidos pela comunidade. Despe-se o processo de sua condição de meio para realização de direitos já formulados e transforma-se ele em instrumento de formulação e realização de direitos. Misto de atividade criadora e aplicadora do direito, ao mesmo tempo (CALMON DE PASSOS, J. J. Democracia, Participação e Processo. In: GRINOVER, Ada Pellegrini; DINAMARCO, Cândido Rangel; WATANABE, Kazuo. Participação e Processo. São Paulo: Editora Revista dos Tribunais, 1988, p. 95).

76 O vértice da democracia ainda é povo, contudo dilatado em sua acepção originária. Este ideário de povo deve, necessariamente, ser compreendido em qualquer indivíduo que seja sujeito de interesses juridicamente tutelados, protegido pela possibilidade de apreciação de seus conflitos e, preponderantemente, como novo partícipe na realização concreta da seara política. A partir daí, observaremos que não se pode mais mirar a democracia unicamente sob a perspectiva procedimental como pretendia Bobbio, posto que ela vai muito além do mero voto nas urnas a cada período eleitoral determinado e tampouco importa a simples manutenção das regras do jogo, já que é dinâmica e se recria diariamente pela práxis (RIBEIRO, Darci Guimarães. Da tutela jurisdicional às formas de tutela. 2010, p. 99).

77 Se, por um lado, a crescente judicialização das relações sociais é resultado do aumento de questões políticas que passaram a ser discutidas também em juízo, vemos, por outro lado, a pressão dos diversos processos de globalização culminar na complexização das relações sociais e na necessidade de se recorrer ao Judiciário para a resolução de conflitos que outrora eram resolvidos nas demais esferas da sociedade. Diante disso, o ativismo judicial nasce em um cenário de alta complexização social e consequente 
Tomado em sentido negativo, o ativismo judicial é atacado por ter como inerente a discricionariedade e, assim, tais decisões seriam, para alguns, de antemão, vazias de legitimidade por incompatibilidade com o Estado Democrático de Direito ${ }^{78}$, enquanto alguns o aceitam como a alternativa "menos pior"79. Pode-se argumentar, todavia, que a crítica à criação do Direito pelo ativismo judicial "tradicional" é baseada na ausência de diferenciação entre os termos Lex e Ius ${ }^{80}$, em que a redução do primeiro à segunda ocorre, principalmente, na esteira da Revolução Francesa ${ }^{81}$ e da teoria da separação de poderes, que relegou o Judiciário à mera boca-da-lei ${ }^{82}$.

De todo modo, o caso brasileiro acaba por demonstrar ser visível que a democracia representativa, que muitas vezes assume feições delegativas ${ }^{83}$, acaba por relegar o povo (e seu poder $\left.^{84}\right)$ à mero objeto de dominação ${ }^{85}$. Dessa maneira, resta premente renovar o interesse na

fragmentação das tradicionais estruturas “a-jurídicas” (como morais e religiosas, por exemplo) de resolução das controvérsias, de modo que podemos distinguir dois pressupostos fenomenológicos fundamentais ao ativismo judicial: reificação e judicialização; esta em uma perspectiva político-institucional, aquela em uma perspectiva sociológica. (TEIXEIRA, Anderson Vichinkeski. Ativismo judicial: nos limites entre racionalidade jurídica e decisão política. Revista direito GV, vol.8, n.1. São Paulo, Jan./Junho 2012. Disponível em: <http://www.scielo.br/scielo.php?script=sci_arttext\&pid=S1808-24322012000100002\&nrm=iso\&tlng=pt>)

78 Também não é possível sustentar qualquer forma de discricionariedade judicial neste momento histórico, uma vez que a discricionariedade está ligada ao subjetivismo (portanto, caudatária do esquema sujeito-objeto), avesso ao paradigma intersubjetivo. Estado Democrático de Direito e discricionariedade são incompatíveis - e essa questão é fulcral (STRECK, Lenio Luiz. Verdade e Consenso: Constituição, hermenêutica e teorias discursivas. 5. ed. rev., atual. e ampl. São Paulo: Saraiva, 2014, p. 75).

79 A legitimidade da justiça constitucional na democracia implica na descrença dos representantes eleitos, considerando-se o juiz como uma alternativa menos pior (BERCOVICI, Gilberto. Soberania e Constituição: para uma crítica do constitucionalismo. São Paulo: Quartier Latin, 2008, p. 324).

8o [...] Pode ocorrer: 1) Que a lei, síntese admirável e fecunda, de toda a realidade, é todo o direito objetivo: e caiba ao intérprete a simples adequação do princípio aos casos em concreto: Ius = Lex; 2) De que todo o direito ou mais do que todo o direito esteja na lei, ou pelo contrário, que pouco se lhe encontre ou quase tudo esteja noutras fontes e manifestações da realidade e da verdade jurídica: Lex x Ius, isto é, no último caso, lei menos ou no primeiro, o que seria difícil, maior que o direito. 3) Que apesar da existência material (proposição escrita) e espiral (intenção) da lei, nenhuma verdade possa tirar-se dela; e então há comparação possível: a lex não é maior nem menor que o direito, e muito menos igual; trata-se de diferença essencial que os faz heterogêneos e insusceptíveis de análise conjunta: não pertence ao direito-ciência o estudo de tal lei, mas ao capítulo da política, referente a teratologia (MIRANDA, Pontes de. Sistema de Ciência Positiva do Direito. Tomo III. Introdução à Ciência do Direito. 2ª Edição. Rio de Janeiro, Editor Borsoi, 1972, p. 289-290).

81 Cfe. GROSSI, Paolo. Mitología jurídica de la modernidade. Madrid: Editorial Trotta, 2003, p. 34.

82 A estrita separação de poderes engendrou uma frágil magistratura, essencialmente confinada ao julgamento dos litígios privados; ela originou um legislativo sem controle; e enquanto ramificação separada dos Tribunais Administrativos, não emergiu como êxito, nem mesmo, igualmente, conseguiu um Executivo sob controle. [...] É muito significativo o fato de que a própria França, onde a doutrina de separação de poderes surgiu, e onde ela sempre foi proclamada, está em vias, depois de algum tempo, de se dirigir neste sentido (assim como em outros países europeus continentais): descartar-se de um rígido sistema de separação de poderes e caminhar na direção da gradual aplicação de um eficaz sistema de controles recíprocos onde o crescimento do Poder Judiciário é, naturalmente, um necessário instrumento complementar do equilíbrio. (CAPPELLETTI, Mauro. Processo, Ideologias e Sociedade. Vol. I. Porto Alegre: Sergio Antonio Fabris Editor, 2008, p. 233-234).

83 Em 1991, Guillermo O’Donnel escreveu um texto chamando a atenção para um fenômeno que estava ocorrendo (e estava por ocorrer) em países da América Latina recentemente saídos de regimes autoritários. Referia-se, pois, a "um novo" tipo/modelo de democracia - a "democracia delegativa", que se fundamenta em uma premissa básica: quem ganha a eleição presidencial é autorizado a governar o país como lhe parecer conveniente, e, na medida em que as relações de poder existentes permitam, até o final de seu mandato. O presidente é, assim, a encarnação da nação, o principal fiador do "interesse maior da nação", que cabe a ele definir. O que ele faz no governo não precisa guardar nenhuma semelhança com o que ele disse durante a campanha eleitoral - afinal, ele foi autorizado a governar como achar conveniente [...]. Depois das eleições, espera-se que os eleitores/delegantes retornem à condição de espectadores passivos, mas quem sabe animados, do que o presidente faz... Esse extremo individualismo no momento de constituir o poder presidencial combina bem com o organicismo do Leviatã hobbesiano: a nação e sua expressão política "autêntica", o "movimento", são postulados como organismos vivos. A nação tem de ser curada e salva pela união de seus fragmentos dispersos em um todo harmônico. A delegação eleitoral/salvacionista inclui não o direito, mas muito mais a obrigação de aplicar à nação remédios amargos que “a curarão” [...] cf. O’Donnel, Guillermo. Democracia Delegativa? Novos Estudos Cebrap, n. 31, São Paulo, Brasileira de Ciências, out. 1991 (STRECK, Lenio Luiz. Jurisdição Constitucional e Decisão Jurídica. São Paulo: Editora Revista dos Tribunais, 2014, p. 51-52).

84 Conforme a Constituição Federal do Brasil: "Art. 1 $1^{\text {a }}$ A República Federativa do Brasil, formada pela união indissolúvel dos Estados e Municípios e do Distrito Federal, constitui-se em Estado Democrático de Direito e tem como fundamentos: I - a soberania; II - a cidadania; III - a dignidade da pessoa humana; IV - os valores sociais do trabalho e da livre iniciativa; V - o pluralismo político. Parágrafo único. Todo o poder emana do povo, que o exerce por meio de representantes eleitos ou diretamente, nos termos desta Constituição".

85 A redução da soberania popularà mera ideologia éo caso praticamentevirulento na realidade dos estados constitucionais modernos O povo é invocado no documento constitucional, ao passo que o seu papel verdadeiro no processo político não é tematizado [...] São sempre os representantes dos representantes que agem pelo povo. O ponto de partida para derivações legitimadoras, idêntico consigo mesmo, evidencia ser uma ficção. O cidadão individual percebe a alegada autonomia [Selbstgesetzgebung] como um ato arbitrário, que ignora seus interesses reais não apenas empiricamente, mas já no plano da lógica. Assim, ocorre uma substituição no 
democracia como participação ${ }^{86}$, a qual desloca o centro do povo ao cidadão, este partícipe na criação não só da lei ou do ato administrativo ${ }^{87}$, mas também do Direito por meio das decisões judiciais, nos trilhos da corrente monista ${ }^{88}$.

Assim é que o processo, além de garantia constitucional contra o arbítrio e subjetivismos ${ }^{89}$, assume a função de ser veículo de concretização da democracia participativa:

A verdadeira práxis democrática, configuradora de um autêntico Estado de Direito, reside principalmente na efetiva concretização dos direitos e garantias fundamentais, e não em meras abstrações legais contidas em um texto normativo. Estes direitos e garantias fundamentais, por sua vez, somente ganham vida através do mais afinado instrumento democrático: o processo ${ }^{90}$.

O fenômeno processual, por meio da compreensão hermenêutica ${ }^{91}$, identifica o pilar da democracia participativa no contraditório, que em sua dimensão constitucional é tido como direito de ser ouvido e influenciar a decisão, símbolo da participação ${ }^{92}$. O contraditório foi caminho da fonte de legitimação para o processo político, que degrada o povo em mero objeto de dominação [...] A palavra povo não é utilizada por vocês para dizer quem seria esse povo, afinal de contas. O povo é pressuposto para que vocês possam falar de outra coisa, mais importante: NÓS SOMOS LEGÍTIMOS" (MÜLLER, Friedrich. Quem é o povo? A questão fundamental da democracia. 3. ed. São Paulo: Max Limonad, 2003, p 36-38 e 44).

86 [...] o adjetivo participação passa a ser o novo referencial em termos democráticos, inserção da (re)qualificação do povo, para além de mero ícone, catapultando-o, assim, para o cenário democrático como ator principal [...] Democracia e participação, nesta perspectiva, se fundem em um conceito unívoco, incindível, capaz de traduzir a um só tempo a exata compreensão da soberania popular. Democracia participativa constitui, nas exatas palavras de Roberto Amaral, "uma tautologia virtuosa" (RIBEIRO, Darci Guimarães. Da tutela jurisdicional às formas de tutela. Porto Alegre: Livraria do Advogado Editora, 2010, p. 100-101).

$87 \mathrm{O}$ discurso acerca da democracia participativa tem sido direcionado às minorias e à inclusão social em termos eminentemente sociológicos. Tanto é assim que, ao mencionarmos a expressão democracia participativa logo se torna presente conceitos como "orçamento participativo" e "fórum social" [...] A alardeada soberania popular dos representantes, que há muito está em crise, abre espaço a novos mecanismos legislativos, como o referendo, o plebiscito e a iniciativa popular. Todos previstos constitucionalmente, mas de rarefeita eficácia, basta analisar nestes vinte anos de constituição quantas vezes nos valemos deles? [...] Portanto, para além da democracia participativa inserida nos âmbitos já citados, devemos concebê-la em seu aspecto verdadeiro: aquela visão de democracia em que o indivíduo está concretamente engajado na busca daquilo que ele entende ser o melhor para si e para a sociedade em que vive, ele é o verdadeiro protagonista dos rumos da sociedade e não mais os seus representantes (RIBEIRO, Darci Guimarães. Da tutela jurisdicional às formas de tutela. Porto Alegre: Livraria do Advogado Editora, 2010, p. 103-104).

$88 \mathrm{Si}$ se aborda el problema desde uma perspectiva monista no tiene sentido plantearse el tema del objeto del processo, al menos como se viene haciendo hasta el presente, como punto de incidencia de las relaciones entre derecho y proceso. No puede señalarse un contenido del processos iudicii distinto de la propria actividad de las partes y del juez. Estas dos fuerzas, en su dinâmica, caminan hacia la búsqueda del derecho que resultará del juicio. La esencia dei proceso es ser génesis del derecho y por lo tanto no puede tratar de objetivarse um contenido en él distinto de la própria actividad procesal. Ahora bien, outra cosa distinta es que quiera señalarse los límites que diversifican un proceso de outro. Efectivamente, el proceso es siempre algo concreto, determinado, y no uma realidad abstracta, estereotipada (MENDEZ, Francisco Ramos. Derecho y Proceso. Barcelona: Libreria Bosch, 1979, p. 273).

89 Devido processo constitucional, cumpre esclarecer, para evitar sofismas e distorções maliciosas, não é sinônimo de formalismo, nem culto da forma pela forma, do rito pelo rito, sim um complexo de garantias mínimas contra o subjetivismo e o arbítrio dos que têm poder de decidir (CALMON DE PASSOS, J. J. Direito, poder, justiça e processo: julgando os que nos julgam. Rio de Janeiro: Forense, 1999, p. 69, grifo do autor)

9o RIBEIRO, Darci Guimarães, Da Tutela Jurisdicional às Formas de Tutela. Porto Alegre: Livraria do Advogado Editora, 2010, p. 106.

91 A compreensão, projetada a partir da "fusão de horizontes", com vistas à interpretação e aplicação aos fatos da vida que nunca acontecem com os mesmos contornos, deverá estar apta a dar conta deste não dito. Vale dizer, o projetar da vida lança os seus desafios e a sua historicidade ao encontro dos textos das normas jurídicas, exigindo a necessária flexibilidade e abertura para buscar sempre novas soluções, aos sempre inéditos contornos estabelecidos pela vida do homem, a qual não vem com um roteiro previamente definidas e programadas. [...] Em suma, "a aplicação é um momento próprio do compreender", ou seja, forma-se um conjunto integrado pela pré-compreensão, compreensão, interpretação e aplicação que é chamado de "círculo hermenêutico. A criatividade que se espera projetada no círculo hermenêutico e do qual deve irradiar pressupõe uma criação do intérprete (notadamente do magistrado), visualizando de forma sistemática o ordenamento jurídico, "que adote ante a sociedade uma postura bastante crítica para superar o sistematismo legal incompatível com a nova necessidade do ordenamento. A proposta hermenêutica esboçada até o momento exigirá uma postura crítica, que esteja interessada em ir um pouco mais além da mera reprodução do texto legal. A cada situação, deverá haver um novo ingresso no círculo hermenêutico, a fim de construir uma solução que seja adequada para "aquele" caso, e especialmente para ele (ENGELMANN, Wilson. Direito natural, ética e hermenêutica. Porto Alegre: Livradora do Advogado Editora, 2007, p. 243-245)

92 A terceira e atual fase, que denomino constitucional e está reconhecida no direito de influenciar, ou como quer N. Trocker no "principio di partecipazione", pode ser bem apreendida por meio das decisões do Tribunal Constitucional Federal Alemão (Bundesverfassungsgericht), em especial esta, segundo a qual: "Essa oitiva é, assim, primeiramente, pressuposto de uma decisão correta. Além disso, a dignidade da pessoa exige que não se disponha sobre seu direito de maneira leviana, com base [somente] na autoridade [estatal]: o indivíduo não só deve ser o objeto da decisão do juiz, como deve ser ouvido antes de uma decisão que envolva seus direitos, a fim de poder ter influência sobre o processo e seu resultado (BVerfGE 7, 53 [57]; 7, 275 [279]. [...] Esta garantia constitucional de poder influenciar significa, nas palavras de Antonio Cabral, "qualquer condicionamento significativo às condutas dos demais sujeitos do processo, realizado a partir de posições críticas ou omissões conclusivas, transmitidas comunicativamente e 
privilegiado no Código de Processo Civil de 2015, estando presente em três artigos das normas fundamentais (arts. $7^{\circ}, 9^{\circ}$ e $10^{93}$ ). Nesse processo mais participativo, o papel do juiz pode sofrer modificações, como, ao estilo alemão, o dever de esclarecimento ${ }^{94}$, presente no saneamento do art. $357, \S 3^{\circ}$, do $\mathrm{CPC} / 2015^{95}$, que contribui para o cumprimento do devido processo legal e a obtenção de uma decisão em tempo razoável ${ }^{96}$. Nessa seara, a fundamentação das decisões, além da obrigatoriedade constitucional (art. 93, IX ${ }^{97}$ ), assume a função de expressar o respeito do magistrado ao contraditório e, por consequência, à democracia, conforme se pode ver principalmente no art. 489, § 1 ${ }^{\circ}, \mathrm{IV}$, do CPC/2015.8.

Partindo dessas premissas, o processo propiciará a construção da decisão judicial pelas partes em colaboração reativa ${ }^{99}$ com magistrado, este dialogando com as primeiras, ou seja, vinculado à dialética ${ }^{100}$ processual que encontra abrigo no contraditório constitucionalizado. $\mathrm{O}$ processo passa adquirir, assim, a dimensão democrática:

que, caso não existissem, poderiam, mantidas as demais condições, motivar o sujeito condicionado a agir de modo diverso (RIBEIRO, Darci Guimarães. A dimensão constitucional do contraditório e seus reflexos no projeto do novo CPC. In: Revista de Processo: RePro, v. 39, n. 232, p. 13-35, 2014, p. 21-22).

93 Art. $7^{\mathbf{0}}$ É assegurada às partes paridade de tratamento em relação ao exercício de direitos e faculdades processuais, aos meios de defesa, aos ônus, aos deveres e à aplicação de sanções processuais, competindo ao juiz zelar pelo efetivo contraditório; Art. $9^{0}$ Não se proferirá decisão contra uma das partes sem que ela seja previamente ouvida; Art. 10 O juiz não pode decidir, em grau algum de jurisdição, com base em fundamento a respeito do qual não se tenha dado às partes oportunidade de se manifestar, ainda que se trate de matéria sobre a qual deva decidir de ofício.

$94 \mathrm{O}$ juiz alemão é tradicionalmente dotado de uma gama ampla de poderes relativos à prova dos fatos. Antes de mais nada, ele deve dialogar e esclarecer com as partes, que têm de fornecer a ele informações completas e verídicas, todos os fatos relevantes da causa, dando às partes as oportunas indicações. Além disso, ele pode dispor de ofício substancialmente de todos os meios de prova, excetuando-se apenas a prova testemunhal. No caso de as partes não terem requerido prova testemunhal que o juiz considera relevante, ele pode, todavia, perguntar às partes se consideraram essa possibilidade e a razão pela qual não fizeram, o que pode facilmente induzir as partes a requerê-la (TARUFFO, Michele. Processo civil comparado: ensaios. São Paulo: Marcial Pons, 2013, p. 66-67).

95 Art. 357 [...] § $3^{\text {o }}$ Se a causa apresentar complexidade em matéria de fato ou de direito, deverá o juiz designar audiência para que o saneamento seja feito em cooperação com as partes, oportunidade em que o juiz, se for o caso, convidará as partes a integrar ou esclarecer suas alegações.

96 RIBEIRO, Darci Guimarães. O saneamento e a organização do processo no novo CPC como direito fundamental à razoável duração do processo. In.: STRECK, Lenio Luiz. ROCHA, Leonel Severo. ENGELMANN, Wilson (Org.) Constituição, Sistemas Sociais e Hermenêutica - Anuário do Programa de Pós-Graduação em Direito da UNISINOS: mestrado e doutorado. Porto Alegre: Livraria do Advogado, São Leopoldo: UNISINOS, 2017, n. 13, p. 32.

97 Art. 93 [...] IX - todos os julgamentos dos órgãos do Poder Judiciário serão públicos, e fundamentadas todas as decisões, sob pena de nulidade, podendo a lei limitar a presença, em determinados atos, às próprias partes e seus advogados, ou somente a estes, em casos nos quais a preservação do direito à intimidade do interessado no sigilo não prejudique o interesse público à informação. 98 Art. 489 [...] § 1 Não se considera fundamentada qualquer decisão judicial, seja ela interlocutória, sentença ou acórdão, que: [...] IV - não enfrentar todos os argumentos deduzidos no processo capazes de, em tese, infirmar a conclusão adotada pelo julgador. 99 No se trata solamente de la pacificación provisional que deriva de un arreglo impuesto por la ley del más fuerte, sino también una armonía restablecida a partir del hecho de que se ha producido un reconocimiento mutuo: cada uno de los protagonistas, cualquiera que sea el tipo de acción que lleve a cabo, ha de poder admitir que la sentencia no es un acto de violência, sino de reconocimiento de los respectivos puntos de vista. En este nível, ascendemos a uma concepción superior de la sociedade: no ya solo um sistema de distribuición de bienes, sinónimo de justicia distribuitiva; sino la sociedade como esquema de cooperación: mediante la distribuición de bienes, pero más allá de la misma, mediante el procedimento, pero más allá del mismo, se deja entrever algo así como un "bien común" que, precisamente, hace de vínculo social. Pero el acto de juzgar no se agota em esta función de separación. Algo más importante es que si es cierto que se produce sobre un transfondo de conflicto social y de violencia larvada, entonces hace falta que el proceso, y el juicio que pone fin al mismo, persigan una función mayor, una alternativa institucional a la violencia, comenzando por la violencia de la justicia que uno se infringe a si mismo. En estas condiciones, sigue P. Ricoeur, "solo aparece el horizonte del acto de juzgar; algo que finalmente es más que la seguridad: la paz social”. Un bien paradójicamente hecho de valores que eminentemente se pueden compartir. En este punto, la dimensión comunitaria ha tomado el relevo de la dimensión procedimental incapaz por sí misma de conjurar la violencia. Podríamos evocar aqui el ejemplo sud-aficano de las comisiones de Verdad y Reconciliación, que "más que juzgar la historia, intenta aligerarla de la semilla del resentimiento que guarda en sus flancos y que puede hacer que se repita”. Estos procedimentos, que son calificados como ejercicios de justicia "reconstructiva" o mejor "transicional”, tratan sin duda de proteger la memoria y los derechos de las víctimas, pero también y, sobre todo, de garantizar aquellas condiciones que vendrían a constrituirse em una especie de conjuro para evitar el retorno del pasado. En resumen, la distribuición judicial es a un mismo tempo tanto la adjucación de unos bienes (que nos separan), como lo que nos hace ser parte de la misma sociedade, esto es, aquello que nos acerca. De esa distribuición surge uma propiedad emergente que es más importante que la parte que se le ha conferido a cada uno; tal es la armonía re-estabelecida, la cooperación reactivada (OST, François. Para qué sirve el derecho? Para contar hasta três. Doxa: Cuadernos de Filosofía del Derecho, Alicante, no 40, p. 15-48, 2017, p. 42-43).

100 É convite à meditação urgente, sobretudo no processo, único depositário normativo (como que de um resíduo) da dialética pelo audiatur et altera pars, princípio-dos-princípios processuais. É indispensável a dialética para uma ciência do processo moderno, que, na sua modernidade, se recuse a voltar às costas para a tradição naquilo que esta tem de mais venerável: o contraditório, dispositivo civilizador, exigência indeclinável tanto para testar asserções e teorias, confrontar opiniões divergentes, quanto para a aplicação contenciosa de normas jurídicas (BORGES, José Souto Maior. O Contraditório no Processo Judicial: uma visão dialética. São Paulo: Malheiros, 1996, p. 50). 
Por tudo isso, o processo hoje só pode ser compreendido dentro de sua dimensão democrática, como um espaço público para os debates, razão pela qual conceituamos processo como "um espaço discursivo intersubjetivo de feições públicas e políticas, na busca de valores socialmente relevantes e que somente pode ser compreendido numa perspectiva constitucionalmente dialógica entre os vários sujeitos envolvidos ${ }^{101}$.

Nesse sentido é que o respeito ao contraditório, ao acesso à justiça, à publicidade e à fundamentação conformam a legitimidade democrática do processo para concretizar as promessas não cumpridas e produzir Direito ${ }^{102}$. Assim configurada, a decisão judicial acaba por se tornar mais apta a receber os influxos sociais e amplificar a adequação existencial por meio do Direito. Nessa esteira, a aceitação pelo Direito da noção de complexidade e de pluralismo jurídico acaba por reconhecer a diferenciação do papel do juiz, a partir de um processo democraticamente legítimo que possa providenciar aberturas ao social ${ }^{103}$.

Assim é que se pode mencionar a possibilidade de um Direito Responsivo, em que a legalidade passa da formalidade (regras para solução de casos individuais) à substancialidade (justiça substantiva). O modelo do direito responsivo representa o Direito como solucionador de problemas a partir de um espírito de autocorreção, cujo início se dá por meio de uma decisão participativa, em que o processo jurisdicional tem grande apelo ${ }^{104}$.

\section{CONSIDERAÇÕES FINAIS}

Conforme apresentado no decorrer do artigo, com a complexificação do mundo na contemporaneidade, apresenta-se a necessidade de superar o paradigma científico cartesiano cunhado na unicidade, o que proporcionou o surgimento da nova racionalidade. Esta, por sua vez, volta a cientificidade para um conhecimento transdisciplinar, dado que pressupõe a destruição das barreiras entre as formas de conhecimento, considerado mais apto a responder aos questionamentos da atual conjectura social.

Assim, a exposição do paradigma da complexidade delineia a necessidade de novas formas de pensar sejam incorporadas pelo Direito, a fim de que este possa propiciar melhores respostas às aspirações sociais de concretização das promessas constitucionais e também de novas demandas. Nesse sentido, principalmente em países de modernidade tardia, em que os insucessos da democracia representativa se fazem mais presentes, o Judiciário surge como alternativa para concretização de direitos.

Nessa esteira, o processo se transforma em instrumento de participação política dos cidadãos em busca de uma sociedade mais justa e igualitária, além da resolução individual de conflitos. A criação de direito por meio da decisão judicial envolve também a possibilidade de saberes transdisciplinares, coadunando-se com o paradigma da complexidade com vistas a garantir a adequação existencial por meio do Direito.

101 RIBEIRO, Darci Guimarães. A dimensão constitucional do contraditório e seus reflexos no projeto do novo CPC. In: Revista de Processo: RePro, v. 39, n. 232, p. 13-35, 2014, p. 22-23.

102 RIBEIRO, Darci Guimarães. Da tutela jurisdicional às formas de tutela. Porto Alegre: Livraria do Advogado Editora, 2010, p. 104-105.

103 Numa abordagem genérica, perante o esgotamento histórico do paradigma legalista e dos seus corolários particularmente os decorrentes da juridificação uniforme das relações sociais, importa trilhar caminhos que permitam uma maior flexibilidade na aproximação jurisdicional, aceitando a complexidade e a pluralidade como um ethos e não, temerosamente, como um pathos e aceitando como imperiosa uma abertura interdisciplinar ao material social e aos próprios métodos da sociologia. Depois, a intervenção do juiz, enquanto vértice do sistema processual, terá, num plano axiológico, que ser orientada de modo a estimular a sua pulsão criativa, numa lógica tópica, de pontos de vista e não de descarnados referenciais silogísticos, num quadro de profunda crise da lei, o que intima a uma intervenção activa, porque reguladora. Já em 1947, um filósofo do direito português referia que o "o direito não está nas normas; está nas conexões inter subjectivas da vida humana, onde se denuncia como realidade concreta e facto de experiência" (MATOS, José Igreja. Um modelo de juiz para o processo civil actual. Coimbra: Editora Coimbra, 2010, p. 153-154). 104 Ver, especialmente o capítulo IV, NONET, Philippe; SELZNICK, Philip. Direito e sociedade: a transição ao sistema jurídico responsivo. Rio de Janeiro: Revan, 2010. 
Perpassando a legitimidade democrática oriunda da representação (voto), o Judiciário se fundamenta no seu irrestrito acesso pelos cidadãos, no contraditório, na fundamentação e na publicidade como pilares de sua legitimidade para agir e concretizar os ideais do Estado Democrático de Direito, além de analisar e se posicionar frente às inevitáveis novas demandas sociais oriundas da complexidade e pluralidade do mundo global.

A conjunção entre a Nova Racionalidade e o Judiciário tem possibilidade de dar mobilidade ao Direito para encarar os desafios dessa nova dinâmica social complexa. Como exemplo, citou-se o modelo do Direito Responsivo, que busca identificar o Direito como solucionador de conflitos e aberto às necessidades sociais. Nesse sentido, o Direito Judicial e sua legitimidade democrática oriunda da nova concepção de democracia participativa, é a porta para a transdisciplinariedade, momento em que poderá ocorrer o diálogo com outras disciplinas científicas, situando-o definitivamente no paradigma da complexidade.

\section{REFERÊNCIAS}

ALHO, Ana Maria Gomes da Silva. Transdisciplinariedade no STF - A ADI n. ${ }^{\circ} 3510$. Anais do XIX Encontro Nacional do CONPEDI.

ARAUJO, Eglis; SOSA, José Gregorio. El Objeto del Derecho desde el contexto de la Multidisciplinariedad, Interdisciplinariedad y Transdisciplinariedad. Una Vision de los Autores. Barquisimeto, Agosto de 2012.

AUGE, Marc. Hacia una Antropología de los Mundos Contemporáneos. Barcelona: Gedisa, 1998.

BAUMAN, Zygmund. Globalização: As consequências humanas. Rio de Janeiro: Jorge Zahar Editor, 1999.

BERCOVICI, Gilberto. Soberania e Constituição: para uma crítica do constitucionalismo. São Paulo: Quartier Latin, 2008.

BORGES, José Souto Maior. O Contraditório no Processo Judicial: uma visão dialética. São Paulo: Malheiros, 1996.

BOURDIEU, Pierre; TEUBNER, Gunther. La fuerza del derecho. Bogotá: Siglo del Hombre Editores. Facultad de Derecho de la Universidad de los Andes, Ediciones Uniandes, Instituto Pensar, 2000.

CALDANI, Miguel Ángel Ciuro. El Derecho Universal (Perspectiva para la Ciencia Jurídica de una Nueva Era). Rosario: Fundaciones para las Investigaciones Jurídicas, 2001.

Miguel Ángel Ciuro. Estrategia Jurídica. Rosario: Consejo de Investigaciones Universidad Nacional de Rosario, 2011.

CALMON DE PASSOS, J. J. Direito, poder, justiça e processo: julgando os que nos julgam. Rio de Janeiro: Forense, 1999. 
CAPPELLETTI, Mauro. Processo, Ideologias e Sociedade. Vol. I. Porto Alegre: Sergio Antonio Fabris Editor, 2008.

CAPRA, Fritjof. El Tao de la Física. Una exploración de los paralelismos entre la física moderna y el misticismo oriental. $9^{\text {a }}$ ed. Malagra: Sirio, 2000.

CARCOVA, Carlos Mária. Las Teorias PostPositivistas. $3^{\underline{a}}$ ed.. Buenos Aires: AbeledoPerrot, 2009 .

CARRIZO, Luis; PRIETO, Mayra Espina; KLEIN, Julie T.. Transdisciplinariedad y Complejidad en el Análisis Social. Gestión de las Transformaciones Sociales (MOST) Documento de Debate. UNESCO. Organizacion de las Naciones Unidas para la Educacion, la Ciencia y la Cultura.

CERUTI, Mauro. El mito de la omnisciencia y el ojo del observador. In: WATZLAWICK, Paul; KRIEG, Peter. El ojo del observador. Contribuciones al constructivismo. Barcelona: Gedisa Editorial, 1995.

COUTURE, J. Eduardo. Introdução ao Estudo do Processo Civil. $3^{\underline{a}}$ Ed. Rio de Janeiro: José Konfino Editor, 1970.

ENGELMANN, Wilson. Direito natural, ética e hermenêutica. Porto Alegre: Livradora do Advogado Editora, 2007.

FAGÚNDEZ, Paulo Roney Ávila. Os novos direitos à luz da transdisciplinaridade: o resgate de um humanismo radical e a promoção da ecologia na sociedade do mal-estar. In: Espaço Jurídico, Joaçaba, v. 9, n. 1, p. 57-66, jan./jun. 2008.

GRINOVER, Ada Pellegrini; DINAMARCO, Cândido Rangel; WATANABE, Kazuo. Participação e Processo. São Paulo: Editora Revista dos Tribunais, 1988.

GROSSI, Paolo. Mitología jurídica de la modernidade. Madrid: Editorial Trotta, 2003.

HINKELAMMERT, Franz. La maldición que pesa sobre la ley. Las raíces del pensamiento crítico en Pablo de Tarso. San José: Costa Rica: Editorial Arlekin, 2010.

KARL, Popper R. Conjecturas y Refutaciones. Brasília: Editora da UnB, 1980.

KUHN, Thomas S. A Estrutura das Revoluções Científicas. $7^{\underline{a}}$ ed. São Paulo: Perspectiva, 2003.

LATAUR, Bruno. Ciência em Ação. Como seguir Cientistas e Engenheiros Sociedade Afora. São Paulo: Editora Unesp, 2000.

MATOS, José Igreja. Um modelo de juiz para o processo civil actual. Coimbra: Editora Coimbra, 2010. 
MATOSI, Nuria Esther Pérez; QUESADAII, Emilio Setién. La interdisciplinariedad y la transdisciplinariedad en las ciencias: una mirada a la teoría bibliológico-informativa. Acimed. 2008;18(4). Disponible en: Dirección electrónica de la contribución.

MELLO Maria F. de; BARROS, Vitória Mendonça de; SOMMERMAN, Américo. Introdução. In: Educação e Transdisciplinaridade II. Coordenação executiva do CETRANS. - São Paulo : TRIOM, 2002.

MENDEZ, Francisco Ramos. Derecho y Proceso. Barcelona: Libreria Bosch, 1979.

MIRANDA, Pontes de. Sistema de Ciência Positiva do Direito. Tomo III. Introdução à Ciência do Direito. 2플 Edição. Rio de Janeiro, Editor Borsoi, 1972.

MORIN, Edgar. Ciência com Consciência. Ed. revista e modificada pelo autor - 8" ed. - Rio de Janeiro: Bertrand Brasil, 2005

Edgar. Da necessidade de um pensamento complexo. Para navegar no século XXI - Tecnologias do Imaginário e Cibercultura. Rio de Janeiro: Bertrand Brasil, 2005.

MÜLLER, Friedrich. Quem é o povo? A questão fundamental da democracia. 3. ed. São Paulo: Max Limonad, 2003.

NONET, Philippe; SELZNICK, Philip. O Direito e Sociedade: a transição ao sistema jurídico responsivo. Rio de Janeiro: Editora Revan, 2010.

OLIU, Alejandro Abal. Derecho Procesal. Tomo I. Segunda Edición, Revisada Y Actualizada. Uruguay: Fundación De Cultura Universitaria, 2001.

OST, François. Para qué sirve el derecho? Para contar hasta três. Doxa: Cuadernos de Filosofía del Derecho, Alicante, no 40, p. 15-48, 2017.

RIBEIRO, Darci Guimarães. A dimensão constitucional do contraditório e seus reflexos no projeto do novo CPC. In: Revista de Processo: RePro, v. 39, n. 232, p. 13-35, 2014

, Darci Guimarães. Da tutela jurisdicional às formas de tutela. Porto Alegre: Livraria do Advogado Editora, 2010.

SANTOS, Boaventura de Souza. Um discurso sobre as Ciências. $7^{\underline{a}}$ ed.. Porto: Edições Afrontamento, 1995.

SANTOS, Paulo Trindade. Filosofia do Direito Processual (da jurisdição ao processo): fenômeno conflitológico de interesses como gênese do Direito. Tese Doutorado. Unisinos, PPGD, São Leopoldo, RS, 2018.

STRECK, Lenio Luiz. Jurisdição Constitucional e Decisão Jurídica. 4. ed. São Paulo: Editora Revista dos Tribunais, 2014. 
Lenio Luiz. ROCHA, Leonel Severo. ENGELMANN, Wilson (Org.) Constituição, Sistemas Sociais e Hermenêutica - Anuário do Programa de Pós-Graduação em Direito da UNISINOS: mestrado e doutorado. Porto Alegre: Livraria do Advogado, São Leopoldo: UNISINOS, 2017, n. 13 .

, Lenio Luiz. Verdade e Consenso: Constituição, hermenêutica e teorias discursivas. 5. ed. rev., atual. e ampl. São Paulo: Saraiva, 2014

TARUFFO, Michele. Processo civil comparado: ensaios. São Paulo: Marcial Pons, 2013.

TEIXEIRA, Anderson Vichnkeski. Ativismo judicial: nos limites entre racionalidade jurídica e decisão política. Revista direito GV, vol.8, n.1. São Paulo, Jan./Junho 2012. Disponível em: <http://www.scielo.br/scielo.php?script=sci_arttext\&pid=S1808-24322012000100002\&nr $\mathrm{m}=\mathrm{iso} \& \mathrm{tlng}=\mathrm{pt}>$.

Transdisciplinarità e Dialogo. Nuova Umanità. XXIX (2007/3) 171, pp. 353-36o.

VILAR, Sergio. La Nueva Racionalidad. Comprender la Complejidad con métodos transdisciplinarios. Barcelona: Editorial Kairós, 1997.

WARAT, Luis Alberto. A Ciência Jurídica e seus Dois Maridos. In: Territórios Desconhecidos. Volume I. A Procura Surrealista pelos Lugares do Abandono do Sentido e da Reconstrução da Subjetividade. Florianopolis: Fundação Boiteux, 2004.

Luis Alberto. Metáforas para a Ciência, a Arte e a Subjetividade. In: Territórios Desconhecidos. Volume I. A Procura Surrealista pelos Lugares do Abandono do Sentido e da Reconstrução da Subjetividade. Florianopolis: Fundação Boiteux, 2004.

Luis Alberto. Territórios Desconhecidos. Volume I. A Procura Surrealista pelos Lugares do Abandono do Sentido e da Reconstrução da Subjetividade. Florianopolis: Fundação Boiteux, 2004. 